Vol 10, Issue 3, 2017

\title{
APOPTOSIS INDUCTION EFFECT OF CURCUMIN AND ITS ANALOGS PENTAGAMAVUNON-0 AND PENTAGAMAVUNON-1 ON CANCER CELL LINES
}

\begin{abstract}
MUHAMMAD DA'I ${ }^{1 *}$, ANDI SUHENDI ${ }^{1}$, EDI MEIYANTO ${ }^{2}$, UMAR A JENIE ${ }^{2}$, MASASHI KAWAICHI ${ }^{3}$
${ }^{1}$ Department of Pharmacy Chemistry, Faculty of Pharmacy, Universitas Muhammadiyah Surakarta, Indonesia. ${ }^{2}$ Departement Molecular Cancer Biology, Cancer Chemoprevention Research Center, Faculty of Pharmacy, Universitas Gadjah Mada, Indonesia. ${ }^{3}$ Division of Gene Function in Animals, Nara Institute of Science and Technology, Ikoma, Japan. Email: Muhammad.Dai@ums.ac.id
\end{abstract}

Received: 24 November 2016, Revised and Accepted: 28 December 2016

ABSTRACT

Objectives: This experiment aims to investigate the apoptosis effect of curcumin and its analogs pentagamavunon-0 (PGV-0) and PGV-1 on normal and other cancer cell lines.

Methods: Growth inhibition effect was investigated using the MTT method. Double staining used acridine orange, 2-(4-aminodiphenyl)-6indolcarbamidine dihydrochloride and ethidium bromide was performed to determine morphological changes of cells. Detection of PARP, caspase-3, PUMA and BAX using a western blot method was conducted to elucidate the apoptosis effect of the compounds.

Results: PGV-1 $(2.5 \mu \mathrm{M})$ and PGV-0 $(5.0 \mu \mathrm{M})$ could inhibit T47D-cell growth on 72 h observation, but not for curcumin. DNA staining showed PGV-1 has the strongest apoptosis induction effect on T47D-cells compared to PGV-0 and curcumin as well. Western blot analysis resulted in cleavage PARP (83 kD) on HeLa, T47D, and MCF-7 cells treated with PGV-1 (2.5 $\mu \mathrm{M})$, PGV-0 (5.0 $\mu \mathrm{M})$. Curcumin $(10.0 \mu \mathrm{M})$ just induced apoptosis on T47D-cell and MCF-7 cell, but not HeLa cell. Cleavage PARP resulted by apoptosis process in the cell. PGV-1 (2.5 $\mu$ M) had a stronger apoptosis effect compared to PGV-0 $(5.0 \mu \mathrm{M})$ and curcumin $(10.0 \mu \mathrm{M})$ based on cleaved PARP result qualitatively. On the normal cell (NH3T3), cells that were treated with the compounds resulted in a negative cleavage PARP. This result indicated that the compounds were part of a selectively induced cancer cell line apoptosis process.

Conclusion: Curcumin, PGV-0 and PGV-1 could inhibit cell growth by induce apoptosis on cancer cells but not on normal cells, which PGV-1 has strongest apoptosis induction effect on cancer cell lines.

Keywords: Curcumin and analogs, Apoptosis, Cancer cell lines.

(c) 2017 The Authors. Published by Innovare Academic Sciences Pvt Ltd. This is an open access article under the CC BY license (http://creativecommons. org/licenses/by/4. 0/) DOI: http://dx.doi.org/10.22159/ajpcr.2017.v10i3.16311

\section{INTRODUCTION}

Curcumin, natural compound of Curcuma sp. had been reported to poses antiproliferative and induce apoptosis on various cancer cell lines [1]. Curcumin is an unstable compound due to the methylene acetone group [2]. Pentagamavunon-0 (PGV-0) and PGV-1 (Fig. 1) are analogs of curcumin and were synthesized and patented by Samhoedi et al. (2004). Both compounds were developed to increase the stability compare to curcumin as a parent compound, by omitting methylene between $\beta$-diketone group of curcumin, which contributed instability of curcumin $[2,3]$.

Previous experiments showed the aromatic region of curcumin and analogs play an important role for the activity of curcumin and analogs $[4,5]$. Curcumin as a parent compound has been investigated for broad spectrum of biological activities. Many experiments showed curcumin could inhibit cancer cell development by inducing apoptosis and inhibiting the cell cycle progression as reviewed by Ravindran et al. [6].

PGV-0 and PGV-1 have been explored for their biological activities, the experiment showed that PGV-0 and PGV-1 possessed a cytotoxic effect $[7,8]$. PGV-1 has a stronger effect to inhibit T47D-cell, which IC50 was $1.74 \mu \mathrm{g} / \mathrm{mL}$ compared to PGV-0 and curcumin, which were 9.39 and $24.97 \mu \mathrm{g} / \mathrm{mL}$, respectively [9]. PGV-0 and PGV-1 combined with doxorubicin could inhibit MCF-7 by apoptosis induction and cell cycle arrest [10].

PGV-0, PGV-1 and curcumin were indicated to inhibit T47D-cell line on G2M phase and induce apoptosis through caspase-3 and caspase-9.
The inhibition on G2M phase was independent of the apoptosis process [11]. A further experiment was needed to investigate the effect of curcumin's analogs PGV-0 and PGV-1 on a different cancer cell line on normal cell.

\section{METHODS}

Materials

HeLa, MCF-7, T47D cancer cells and NIH3T3 normal cell were provided by Prof. Masashi Kawaichi (NARA Institute of Science and Technology, Japan). Cells were cultured in DMEM medium and supplemented with $5 \%$ fetal bovine serum (Gibco), $100 \mathrm{U} / \mathrm{ml}$ penicillin and $100 \mu \mathrm{g} / \mathrm{ml}$ streptomycin. Curcumin analogs (PGV-1 and PGV-0) were prepared at Gadjah Mada University, and curcumin was purchased from E-Merck.

\section{Cells growth test}

Harvested cells were seeded onto 96 well plates $(3,000$ cells in each well) in $100.0 \mu \mathrm{l}$ culture medium, and incubated for $24 \mathrm{hrs}$ in $\mathrm{CO}_{2} 5 \%$, $37^{\circ} \mathrm{C}$. $100.0 \mu \mathrm{l}$ sample was added with the final concentration of PGV-1, PGV-0 and curcumin were 2.5, 5.0 and $10.0 \mu \mathrm{M}$, respectively. The cells were incubated for 6, 12, 24, 48 and 72 hrs. After time incubation, the medium was discarded and cells were washed using PBS pH 7.4 and replaced with $100.0 \mu$ l culture medium and added with $15.0 \mu \mathrm{l}$ MTT ( $5 \mathrm{mg} / \mathrm{ml}$ ) and followed by a 6 hrs incubation period. The formazan was diluted in $10 \%$ SDS $\mathrm{HCl}(0.1 \%)$. The result was measured using enzyme-linked immunosorbent assay reader $(550 \mathrm{~nm})$. 


\section{DNA cell staining}

Harvested cells $\left(1.5 \times 10^{4}\right)$ was seeded on sterile cover slips in 24 well plates and incubated to get $50 \%$ confluence. Cells were incubated with samples for $24 \mathrm{hrs}$ in a $5 \% \mathrm{CO}_{2}$ incubator, $37^{\circ} \mathrm{C}$. The medium was discarded, and cells were added with ethidium bromide $0.5+0.15 \%$ acridine orange in $95 \%$ ethanol solution for 5 minutes. DNA morphology was observed under a fluorescent microscope (Zeiss MC-80). The same procedure was conducted for staining using 2-(4-aminodiphenyl)-6indolcarbamidine dihydrochloride (DAPI) $0.1 \%$ in aquabidest.

\section{Western blot analysis}

An equal amount of proteins from cell lysates were solubilized five times of the sample buffer and electrophoresed in $10-15 \%$ sodium dodecyl sulfate-polyacrilamide gels and transferred to the polyvinylidene difluoride membrane. The membranes were first incubated with either primer antibody against cleavage PARP, caspase-3, caspase-7 were purchased from cell signaling technology) PUMA (proscience), BAX (abcham), normalized using tubulin (abcham), and then with a horseradish peroxidase-conjugated secondary antibody (cell signaling technology). An enhanced chemiluminescence system (Amersham) was used to detect the proteins. All methods were adopted from the manufacturer with modification.

\section{RESULTS}

Inhibition of cell proliferation could be observed by investigating the profile of cell growth. The absorbance of formazan that indicated viable cells could be converted as a percentage of viable cells and indicated the ability of the samples to inhibit cell growth. This experiment showed PGV-1 $(2.5 \mu \mathrm{M})$ and PGV-0 $(5.0 \mu \mathrm{M})$ could inhibit T47D-cell growth on a $72 \mathrm{~h}$ observation, but not for curcumin $(10.0 \mu \mathrm{M})$ (Fig. 2). Inhibition of cell growth by the compounds is strongly related with the ability of the compound to induce apoptosis or cell cycle arrest.

DNA staining of the cells that was induced by the compound using (ethidium bromide+acridine orange) and DAPI could be applicated to investigate the change of DNA morphology. The result showed PGV-1 has the strongest apoptosis induction effect on T47D-cells compared to PGV-0 and curcumin as well (Fig. 3). Cells were treated using PGV-1 indicated apoptosis DNA, showed by the fragmented DNA (indicated with a red arrow).

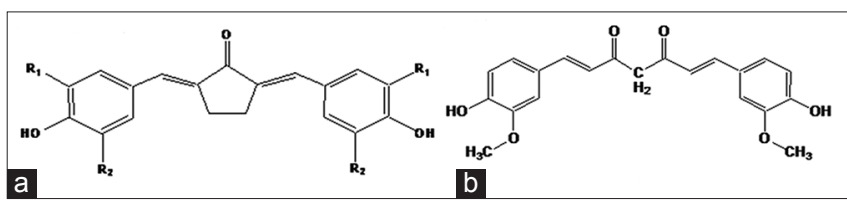

Fig. 1: Curcumin analogs. (a) R1 =-OCH3, R2=H (pentagamavunon-0 [PGV-0]) and R1=R2=-CH3 (PGV-1), were monocarbonyl curcumin analogs, previous experiments showed that they possess more stable and have better biological activity compare to (b) curcumin as the parent compound
The result showed T47D-cells treated with test compounds indicated apoptosis of the DNA and some cells showed a multilobular nucleus. Cells became bigger and multinucleus, indicated chromatin condensation, and failed to divide. The Apoptosis process recruited a complex mechanism and should be analyzed further using western blot methods, including for the other cell lines.

Western blot analysis was performed on HeLa cell (cervical cancer cell invected with human papillomavirus-18) express protein E6 and E7 that disrupt $\mathrm{p} 53$ and pRb suppressor protein [12-14]. The experiment also was conducted on MCF-7, a breast cancer cell line that expresses normal p53 protein [15], but does not express caspase-3 [16] compared to the other breast cancer cell lines type T47D that had mutation on p53 gen [17]. The experiment was compared to NIH3T3, normal cell omitted from mice fibroblast [12].

Western blot analysis resulted in PARP cleavage (83 kD) on HeLa, T47D, and MCF-7 cells treated with PGV-1 $(2.5 \mu \mathrm{M})$, PGV-0 $(5.0 \mu \mathrm{M})$. Curcumin $(10.0 \mu \mathrm{M})$ just induced apoptosis on T47D-cell and MCF cell but not on HeLa cell (Fig. 4). PARP cleavage resulted by an apoptosis process in the cell [18]. These results also show that PGV-1 $(2.5 \mu \mathrm{M})$ had a stronger apoptosis effect compared to PGV-0 $(5.0 \mu \mathrm{M})$ and curcumin $(10.0 \mu \mathrm{M})$ based on PARP cleavage result qualitatively. On the normal cell (NH3T3), cells that were treated with the compounds resulted in a negative PARP cleavage. This result indicated that the compounds were selectively induced cancer cell line apoptosis process.

Further investigation of PGV-1 showed apoptosis induction on T47Dcells trough caspase- 3 activation independent PUMA and BAX. On the other hand, apoptosis induction on MCF-7 cells-even without caspase-3 expression-was related with PUMA and BAX protein. On HeLa cells, apoptosis induction was not related with PUMA and BAX expression and did not depend on caspase- 3 activation. These findings indicate that PGV-1 could induce apoptosis on cancer cell lines with normal p53 or mutation of p53. Cells that express p53 normally, apoptosis resulted through an intrinsic pathway and recruited pro apoptosis protein such as PUMA and BAX (Fig. 4).

\section{DISCUSSION}

Curcumin, PGV-0 and PGV-1 induced apoptosis on MCF-7 cells. Apoptosis induction on MCF-7 cells indicated that curcumin could induce apoptosis through accumulation of cells on the G2M phase followed by the increase of the p53, p21 expression and release of cytochrome C from the mitochondria [19]. This mechanism is similar with antimicrotubule drugs, Taxol could induce apoptosis through an increase in the level of p53 and p21, which is followed by decreased Bcl-2 and induce activation of caspase-9 [20]. This result supported the previous research that paclitaxel could induce apoptosis through phosphorylated $\mathrm{Bcl}-2$ and increased expression of BAX through activated PKA (cyclic adenosine monophosphate-dependent protein kinase) pathway [21]. N-phenyl-N'-(2-chloroethyl) ureas had been

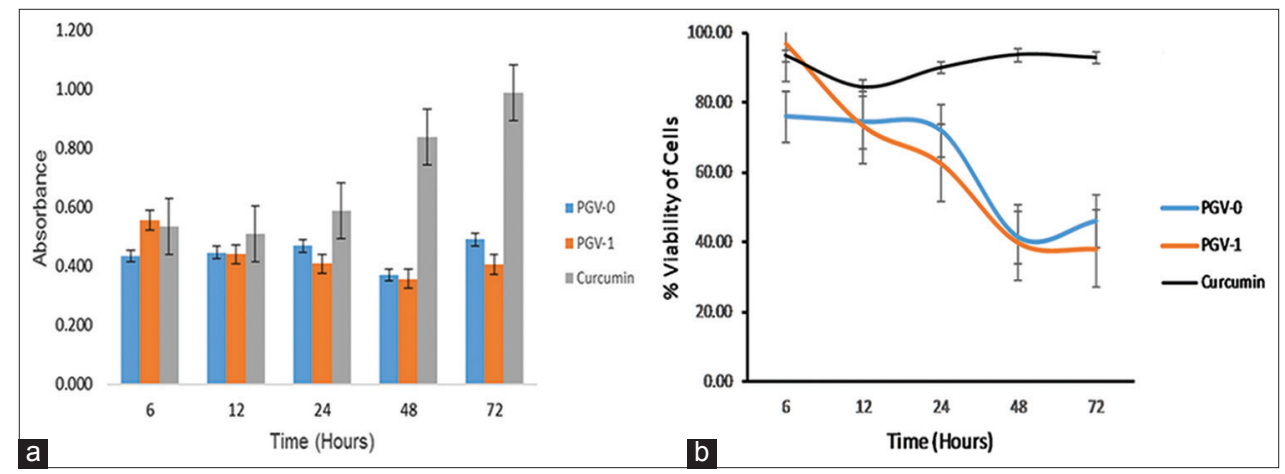

Fig. 2: The effect of pentagamavunon-0 (PGV-0) $(5.0 \mu \mathrm{M}), \mathrm{PGV}-1$ (2.5 $\mu \mathrm{M})$ and curcumin $(10 \mu \mathrm{M})$ on T47D cells, (a) absorbance of formazan, (b) percentage of viability T47D-cells. PGV-1 (2.5 $\mu \mathrm{M})$ inhibited stronger compared to PGV-0 (5 $\mu \mathrm{M})$ and curcumin (10 $\mu \mathrm{M})$ 


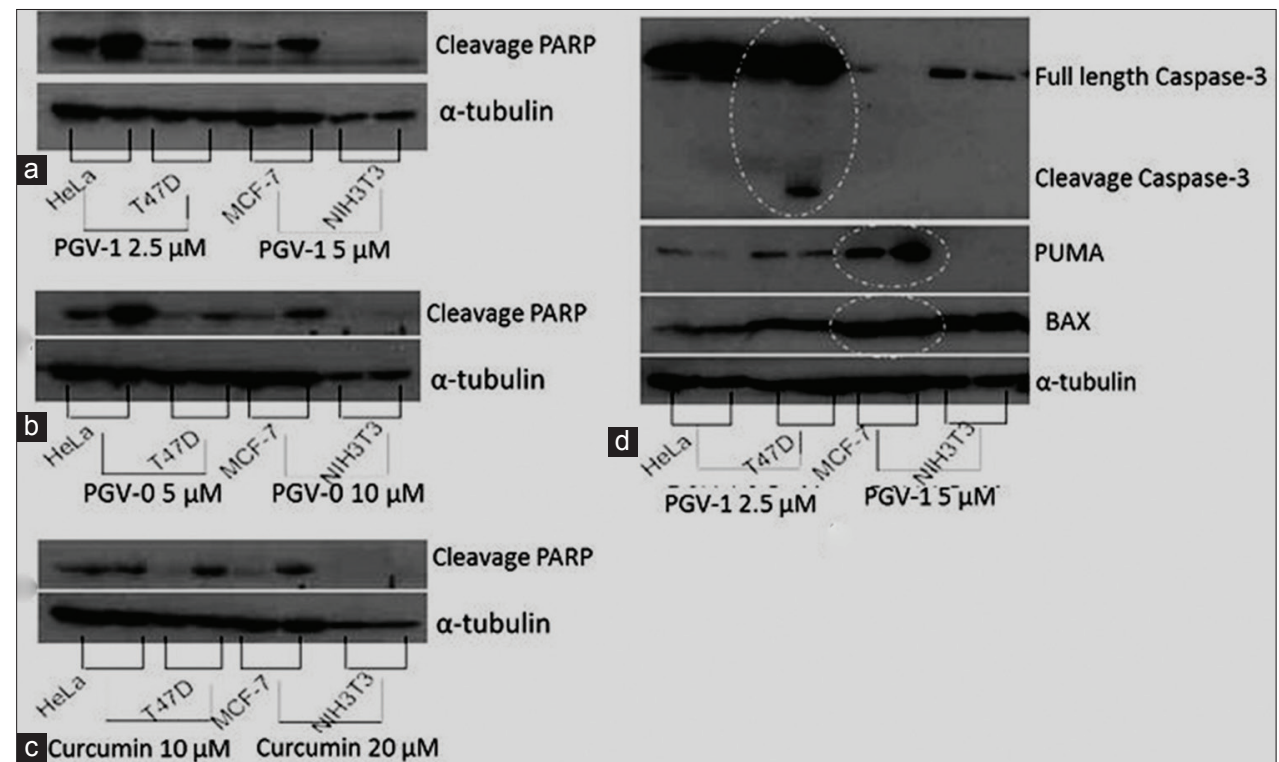

Fig. 3: Pentagamavunon-1 (2.5 $\mu \mathrm{g} / \mathrm{mL})$. (a) And PGV-0 (5.0 $\mu \mathrm{g} / \mathrm{mL})$, (b) induced apoptosis on HeLa, T47D and MCF-7. On higher concentration, both compounds could not induce apoptosis on NIH3T3 (normal cell) curcumin, (c) induced apoptosis on T47D and MCF-7 but not on HeLa and NIH3T3, (d) Further investigation of PGV-1 could activate caspase-3 on T47D-cells but not on HeLa and NIH3T3, increased PUMA and BAX on MCF-7 cell but not on HeLa and NIH3T3 cell

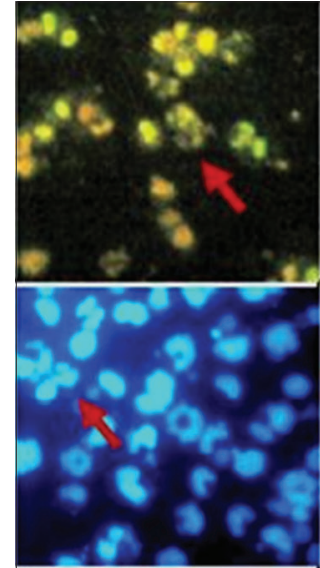

A. PGV-1 $5 \mu \mathrm{M}$

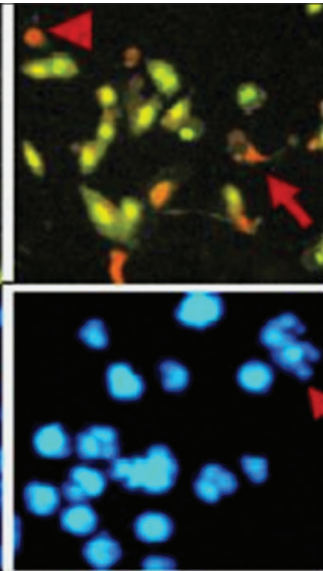

B. Curcumin 20 uM

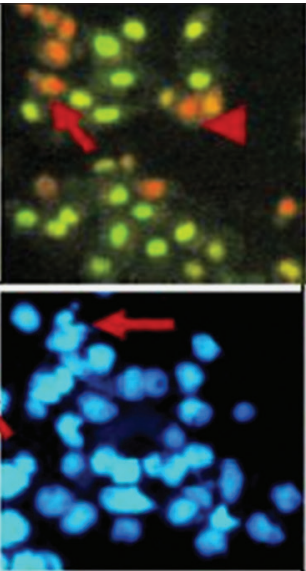

C. PGV-0 $20 \mu \mathrm{M}$

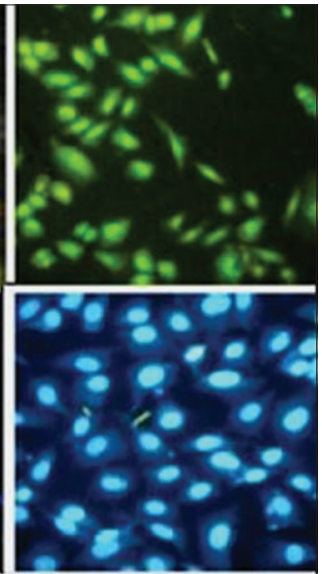

D. Negative contro

Fig. 4: (A) Pentagamavunon-1 (PGV-1) $(5 \mu \mathrm{g} / \mathrm{mL})$ induced apoptosis cell stronger compared to (B) curcumin (20 $\mu \mathrm{g} / \mathrm{mL})$, (C) PGV-0 $(10 \mu \mathrm{g} / \mathrm{mL})$, and (D) control cell. Apoptotic cells were investigated by staining T47D cells using acridine orange: Ethidium bromide (1:1) (Line 1) and DAPI (Line 2). Apoptosis cells showed a fragmented nucleus

reported as an antiproliferative on several cancer cell lines that could induce apoptosis through translocation of BAX that activate caspase to induce apoptosis [22]. Further investigation indicated that PGV-1 could elevate PUMA and BAX, pro apoptosis protein, and resulted in PARP cleavage as indicator. Apoptosis induction on MCF-7 did not involve caspase-3 activation since MCF-7 is not express caspase-3 [16,22-24]. This might involve other apoptosis intrinsic pathway that needed other protein apoptosis effector.

PGV-1 and PGV-0 induced apoptosis on HeLa cells, but not curcumin. Further investigation showed apoptosis on HeLa cells not related with level of PUMA, BAX and caspase-3 activation (Fig. 4). It might be caused by protein E6 that was expressed by HeLa cells that degraded p53 as a transcription factor of PUMA and BAX $[13,14]$. Apoptosis induction on HeLa cells might involve and extrinsic pathway. Taken together, curcumin analogs could induce apoptosis on T47D, MCF-7 and HeLa cells dependent or independent p53.

Further investigation showed curcumin, PGV-1 and PGV-0 did not induce apoptosis on normal cell NIH3T3, PARP cleavage was not shown after
$24 \mathrm{~h}$ treatment by those compounds. A higher concentration of PGV-1 also did not induce apoptosis. After $24 \mathrm{~h}$ of being induced by PGV-1, NIH3T3 could not activate caspase-3, did not express PUMA, and there was no different level of BAX. All of these results indicated curcumin, PGV-1 and PGV-0 induced apoptosis on cancer cell selectively. Curcumin analogs PGV-0 and PGV-1 are promising to be further developed to support cancer therapy.

\section{CONCLUSION}

Curcumin, PGV-0 and PGV-1 could inhibit cells growth by induced apoptosis on cancer cells but not on normal cells, which PGV-1 has the strongest apoptosis induction effect on cancer cell lines.

\section{REFERENCES}

1. Elgadir MA, Salama M, Adam A. Anti-breast cancer from various natural sources - Review. Int J Pharm Pharm Sci 2015;7(2):44-7.

2. Tønnesen HH, Karlsen J. Studies on curcumin and curcuminoids. VI. Kinetics of curcumin degradation in aqueous solution. Z Lebensm Unters Forsch 1985;180(5):402-4. 
3. Van der Good H. The chemistry and qualitatitve structure activity relationships of curcumin, in recent development in curcumin pharmacochemistry. In: Pramono S, editor. Proceedings of International Symposium on Curcumin Pharmacochemistry (15cp). YogyakartaIndonesia. August, 29-31; 1995.

4. Robinson TP, Ehler T, Hubbard RB, Bai X, Arbiser JL, Goldsmith DJ, et al. Design, synthesis and biological evaluastion of aromatic enones related to curcumin. Bioorg Med chem Lett 2003;13(1):115-7.

5. Adams BK, Ferstl EM, Davis MC, Herold M, Kurtkaya S, Camalier RF, et al. Synthesis and biological evaluation of novel curcumin analogs as anti-cancer and anti-angiogenesis agents. Bioorg Med Chem 2004;12(4):3871-83.

6. Ravindran J, Prasad S, Aggarwal BB. Curcumin and cancer cells: How many ways can curry kill tumor cells selectively? AAPS J 2009;11(13):495-510.

7. Meiyanto E, Da'i MS, Agustina D. Antiproliferative effect of pentagamavunon-0 on breast cancer cell line T47D. J Kedokt Yarsi 2006;14(1):11-5

8. Meiyanto E, Agustina D, Supardjan AM, Da'i M. PGV-O induces apoptosis on T47D breast cancer cell lines through caspase-3 activation. J Kedokt Yarsi 2007;15(2):75-9.

9. Da'i M, Supardjan AM, Meiyanto E, Jenie UA. Geometric isomers and cytotoxic effect on T47D cells of curcumin analogues PGV-0 and PGV-1. Majalah Farmasi Indones 2007;18(1):40-7.

10. Hermawan A, Fitriasari A, Junaedi S, Ikawati M, Haryanti S, Widayarti B, et al. PGV-0 and PGV-1 increased apoptosis induction of doxorubicin on MCF7 breast cencer cells. Pharmacon 2011;12(2):55-9.

11. Da'i M, Supardjan AM, Jenie UA, Kawaichi M, Meiyanto E. Pentagamavunon-1 menghambat siklus sel T47D terinduksi caspase inhibitor Z-VAD-Fmk pada fase G2-M. J Farmasi Indones 2012;5(4):180-7

12. ATCC. Available from: https://www.atcc.org/Products/All/30-2007. aspx.

13. Dyson N. The regulation of E2F by pRB-family proteins. Genes Dev 1998;2(15):2245-62.

14. Lagunas-Martínez A, Madrid-Marina V, Gariglio P. Modulation of apoptosis by early human papillomavirus proteins in cervical cancer.
Biochim Biophys Acta 2010;1805(1):6-16.

15. Wosikowski K, Regis JT, Robey RW, Alvarez M, Buters JT, Gudas JM, et al. Normal p53 status and function despite the development of drug resistance in human breast cancer cells. Cell Growth Differ 1995;6(11):1395-403.

16. Janicke RU, Sprengart ML, Wati MR, Porter AG. Caspase-3 is required for DNA fragmentation and morphological changes associated with apoptosis. J Biol Chem 1998;273(16):9357-60.

17. Lim LY, Vidnovic N, Ellisen LW, Leong CO. Mutant p53 mediates survival of breast cancer cells. Br J Cancer 2009;101(9):1606-12.

18. Chaitanya GV, Alexander JS, Babu PP. PARP-1 cleavage fragments: Signatures of cell-death proteases in neurodegeneration. Cell Commun Signal 2010;8(31):1-11.

19. Choundhuri T, Pal S, Agrawal ML, Dasa T, Sa G. Curcumin induces apoptosis in human breast cancer cell trough p53-dependen bax induction. FEBS Lett 2002;512(1-3):334-40.

20. Pannoa ML, Giordanoa F, Mastroiannib F, Morelli C, Brunelli E, Palma MG, et al. Evidence that low doses of taxol enhance the functional transactivatory properties of $\mathrm{p} 53$ on $\mathrm{p} 21$ waf promoter in MCF-7 breast cancer cells. FEBS Lett 2006;580(9):2371-80.

21. Srivastava RK, Srivastava AR, Korsmeyer SJ, Nesterova M, Cho-Chung YS, Longo DL. Involvement of microtubules in the regulation of Bcl2 phosphorylation and apoptosis through cyclic AMP-dependent protein kinase. Mol Cell Biol 1998;18(6):3509-17

22. Fortin JS, Cote MF, Deschesnes RG, Lacroix J, Patenaude A, Biancamano $\mathrm{MO}$, et al. Microtubule disrupting N-phenyl-N'-(2chloroethyl) ureas display anticancer activity on cell adhesion, P-glycoprotein and BCL-2-mediated drug resistance. Int J Pharm Pharm Sci 2014;6(2):171-9.

23. Devarajan E, Chen J, Multani AS, Pathak S, Sahin AA, Mehta K. Human breast cancer MCF-7 cell line contains inherently drug-resistant subclones with distinct genotypic and phenotypic features. Int J Oncol 2002;20(5):913-20.

24. Zhang GP, Lu YY, Lv JC, Ou HJ. Effect of ursolic acid on caspase-3 and PARP expression of human MCF-7 cells. Zhongguo Zhong Yao Za Zhi 2006;31(2):141-4. 